Drs. H.C. Dekker

\title{
European Accounting Association
}

In het novembernummer 1979 van dit maandblad heb ik de lezers voor het eerst kunnen informeren omtrent het bestaan, de werkwijze en het tweede congres van de European Accounting Association (EAA). Vrij recent heeft de lezer in het februari/maart 1981 nummer van dit maandblad kennis kunnen nemen van een aantal congrespapers van het derde jaarcongres in Amsterdam. Het lijkt derhalve een goede gedachte om in dit blad tevens enige aandacht te besteden aan het vierde jaarcongres van de EAA, dat in april j.l. heeft plaatsgevonden te Barcelona. De congresbezoekers waren daar de gast van IESE (Instituto de Estudias Superiores de la Empresa), een in 1958 door de Universiteit van Navarra opgerichte postacademische opleiding Bedrijfseconomie. Het IESE heeft een staf van 37 full-time en 36 part-time docenten. De werkzaamheden van de full-time staf zijn qua tijdsbesteding als volgt opgebouwd:

$50 \%$ onderwijs en onderzoek

$25 \%$ bestuurlijke en beheersactiviteiten t.b.v. IESE

$25 \%$ als adviseur of manager van een onderneming.

Vooral dat laatste is een aspect waar menig academisch docent met enige afgunst naar zal kijken.

Met welkomstwoorden van EAA-voorzitter Prof. Dr. J. L. Bouma en van de plaatsvervangend decaan van IESE, Prof. P. Nueno, die in het kort de geschiedenis en filosofie van dit instituut schetste, werd het jaarlijks congres op 13 april jl. geopend. Hierna kwamen achtereenvolgens Prof. E. F. Peña en Don Carlos Cubillo Valverda aan het woord.

Prof. Peña schetste in het kort de werkzaamheden van de AECA (Asociacion Española de Contabilidad y Administración de Empresa). Deze vereniging is opgericht in 1979 door hoogleraren, ondernemingsbestuurders en professionele accountants uit zowel de private als de publieke sector. Het hoofddoel van AECA betreft enerzijds het bevorderen en verrichten van onderzoek naar verslaggevingsproblemen (in een Spaanse context) en anderzijds het ontwikkelen van richtlijnen en standaards voor de waardering en de verslaggeving van ondernemingen en het bevorderen van wetgeving op dit gebied. Tijdens de twee jaren van haar bestaan heeft AECA twee rapporten gepubliceerd, een over 'De waardering van ondernemingen en hun onderdelen', de tweede betrekking hebbend op 'Uitgangspunten en standaards inzake verslaggeving in Spanje en het buitenland'. 
Spreker concludeerde dat de werkzaamheden van AECA bevredigend verlopen doch dat er nog veel werk door het instituut valt te verrichten. De officiële openingsrede 'Presente y futuro de la Planificación Contable en España' werd uitgesproken door Don Carlos Cubillo Valverda, directeur van het 'Instituto de Planificación Contable'. Sprekergaf een overzicht van de huidige wettelijke fundamenten van de financiële verslaggeving in Spanje en van de bestaande plannen voor de toekomstige ontwikkelingen daarin.

Sinds 1973 heeft Spanje een door de regering goedgekeurd 'Plan General de Contabilidad' (PGC). Aan dit 'plan' is vanaf 1965 gewerkt door 20 commissies, ieder voor een aparte bedrijfstak of sector. Vanwege het ontbreken van gemeenschappelijke uitgangspunten, terminologie en definities bleek het coördineren van de afzonderlijke resultaten van die commissies een onmogelijke taak. Een gemeenschappelijk raamwerk werd gevonden in het Franse 'Plan Comptable'. Het raamwerk van het Spaanse PGC bestaat dan ook uit:

1. een stelsel ('code') van rekeningen

2. definities en relaties

3. jaarverslag en toelichting

4. waarderingsgrondslagen.

Met uitzondering van het element 'definities en relaties' ging spreker uitgebreid op het PGC in. Het voert in het kader van dit artikel te ver om hiervan een uitgebreide weergave te geven. ${ }^{1} \mathrm{Ik}$ beperk mij dan ook tot die aspecten die m.i. het meest interessant zijn.

Ad 1. Het stelsel van rekeningen kent een decimale indeling en vertoont een grote gelijkenis met het Franse stelsel.

Ad 3. Het jaarverslag dient te bevatten:

- een balans (plus toelichting)

- een exploitatie-rekening

- een rekening van buitengewone resultaten

- een overzicht van de financiële resultaten van beleggingen

- een winst- en verliesrekening

- een staat van herkomst en besteding of een overzicht van balansmutaties. Daarnaast schrijft de belastingwetgeving bepaalde rekeningen voor die representatief zijn voor specifieke situaties.

Ad 4. Bij de winstbepaling wordt uitgegaan van het continuilteitsprincipe, het beginsel van de bestendigheid en het toerekeningsbeginsel. Als waarderingsgrondslag geldt de historische kosten. Er bestaan in Spanje, m.u.v. enkele op zich staande gevallen geen regelingen betreffende consolidatie.

$\mathrm{Na}$ bespreking van het PGC schetste de inleider de invloed die de invoering van de moderne uitgangspunten betreffende 'accounting' heeft gehad. Het heeft geleid tot geweldige activiteiten qua onderzoek, publicatie van artikelen en handboeken, onderwijs en meningsvorming binnen het accountantsberoep teneinde de vele nieuwe ideëen toepasbaar te maken voor Spanje.

Voor de toekomst zag de heer Cubillo een verdergaande internationalisatie van handel en industrie, onder meer als gevolg van het toetreden van Spanje tot de Europese Gemeenschap. Deze ontwikkeling zal leiden tot een vergrote vraag naar gemeenschappelijke regels betreffende de openheid in de verslag- 
geving, met name de aanpassing van de Spaanse wet aan de Vierde EEGRichtlijn.

Aan het eind van zijn rede spoorde de heer Cubillo de congresdeelnemers aan om instrumenten te ontwikkelen waarmee de bestaande dringende problemen kunnen worden opgelost, waarbij met name de problemen betreffende de 'inflation-accounting' werden genoemd. Na deze openingsrede gingen de 169 congresdeelnemers uit 19 landen aan het werk om in 17 'concurrent' werkgroepbijeenkomsten 55 papers te bespreken. Dit aantal papers brak het record van 54 dat tijdens het derde congres te Amsterdam werd gepresenteerd.

De werkgroepbijeenkomsten, verdeeld over drie dagen hadden betrekking op:

- accounting and economic systems (twee bijeenkomsten)

- accounting and capital markets

- inflation accounting

- social accounting

- multinational accounting (twee bijeenkomsten)

- accounting policy: government regulation of accounting practices

- accounting and management science

- auditing

- methodology

- internal accounting

- cash-flow accounting

- EEG-richtlijnen

- accounting history

- comparative accounting

- een open forum waar congresdeelnemers een inleiding en een overzicht konden geven van hun lopende onderzoeksprojecten.

Twee van de dertien Nederlandse congresdeelnemers hebben tijdens deze werkbijeenkomsten een paper gepresenteerd. ${ }^{2}$

Aan het eind van de tweede congresdag stond een lezing van S. A. Zeff (editor van The Accounting Review) over het onderwerp 'The International Harmonization of Accounting Standards: The Forces at Play' op het programma.

Zeff betoogde dat de term 'harmonisatie van accounting standaards' dubbelzinnig van aard is. Met behulp van vijf observaties maakte hij dit duidelijk.

1. 'Harmonisatie', een uitvloeisel van het verdrag van Rome (1957), verscheen voor het eerst in de accounting-literatuur in 1967 tijdens het 9e Internationale accountants congres.

2. Rechtsgeleerden hebben alle mogelijke moeite gedaan het begrip te definiëren. Zeff verbindt daaraan de conclusie dat het wellicht het beste is het net zo mistig te laten als het proces dat het probeert te beschrijven is: onderhandeling tussen internationale vertegenwoordigers teneinde een compromis te bereiken dat op een aanvaardbaar niveau internationale vergelijking vergemakkelijkt.

3. Hoewel de term 'harmonisatie' regelmatig wordt gebruikt bij EEG-'accounting' zaken gebruikt de Vierde Richtlijn de term 'coördinatie'.

4. 'Harmonisatie' is sindsdien ook buiten de EEG verspreid, hoewel de criteria die vergelijking mogelijk moeten maken en zich op doeltreffende wijze bezighouden met verschillende omstandigheden even duister blijven als daarvoor. 
5. De begrippen 'standaard' en 'vaststellen van standaard' zijn van recente oorsprong, hoewel er in de vroegere literatuur reeds verwijzingen ernaar zijn te vinden. Tot 1970 was het begrip 'accounting principles' het meest gebruikt. Zeff beschreef hier met behulp van o.m. publicaties door de beroepsorganisaties in verschillende leidinggevende landen op het gebied van regelgeving, het proces waarin de term 'accounting principles' werd vervangen door 'accounting standards'. Hij suggereerde dat deze nieuwe terminologie wellicht de rol van onderzoek en die van de ontwikkeling van grondslagen in verhouding tot het vaststellen van standaards erkent. Aan de andere kant stelde hij dat het niet kan worden tegengesproken dat 'standard' waarschijnlijk een politieke dimensie toelaat, welke dimensie moeilijk is te vinden in het begrip 'principles'.

Vervolgens hield Zeff een warm pleidooi onderzoek te verrichten naar de wijze waarop het vaststellen van standaards door de verschillende instanties plaatsvindt. Omtrent dergelijke besluitvormingsprocessen is nog weinig bekend. Het is zaak er spoedig mee te beginnen omdat de 'data-base' voor dergelijk onderzoek snel veroudert. Met het voortschrijden van de tijd verliezen de hoofdpersonen in deze processen hun herinneringen m.b.t. de factoren die in discussie kwamen, vernietigen zij hun persoonlijke archieven en daarmee niet-gepubliceerd belangwekkend materiaal en verdwijnen zij wellicht zelf van het toneel. Zeff stelde dat men veilig kan aannemen dat de gepubliceerde verklaringen veelal niet de echte verklaringen zijn. Hij vervolgde met erop te wijzen dat in een dergelijk onderzoek niet slechts kan worden volstaan met de schriftelijke correspondentie doch dat ook een greep dient te worden verkregen op telefoongesprekken en snel bijeengeroepen vergaderingen die beide weinig sporen van bewijs achterlaten. Het onderzoek naar het proces van vaststelling van accounting-standaards is pas recent begonnen. Spreker behandelde voorts tien factoren die harmonisatie bevorderen:

$a$. de pers, zowel als medium en als criticast. Wat is de invloed van de pers geweest op het gebied van harmonisatie van accounting standaards?

$b$. tekstboeken; Amerikaanse tekstboeken worden over de gehele wereld bestudeerd. Tot op welke hoogte heeft dit geleid tot het overbrengen van de 'accounting'-technologie?

c. de groei van multinationale ondernemingen en het feit dat regulerende instanties als SEC voorschrijven voor de Amerikaanse vestigingen de 'generally accepted accounting principles' toe te passen. In hoeverre wordt de economische invloed gevolgd door een 'accounting' invloed?

$d$. de fusies van accountantskantoren en de internationale samenwerking daartussen;

e. het toenemende belang van internationale vermogensmarkten;

$f$. de activiteiten van internationale geldleners bij het aanmoedigen om internationaal geaccepteerde accounting praktijken te aanvaarden door lenenden in ontwikkelingslanden;

g. acties en aanbevelingen van IASC en OECD;

$h$. acties van regionale groeperingen als UEC;

$i$. het in andere landen afnemen van examens door daartoe bevoegde lichamen;

j. de gewoonte van studenten om hun accounting opleiding in het buitenland 
te volgen en daarna in eigen land het beroep uit te oefenen of te doceren. Daar staan, aldus Zeff, zeven tegenwerkende krachten tegenover:

a. nationale trots;

b. verschillende in de verslagen geïnteresseerden met ieder een eigen informatiebehoefte (bijv. beleggers versus werknemers);

c. verschillende doeleinden van de verslagen;

$d$. verschillen in ontwikkelingen van de vermogensmarkten;

$e$. verschillende wettelijke regimes;

$f$. conflicten tussen de partijen die een invloed op het proces van standaard vaststelling proberen te krijgen;

g. economische gevolgen (bijv. segmentrapportering na de fusiegolf, SECrelease 90 als gevolg van de anti-inflatiepolitiek van president Ford).

Zeff besloot zijn lezing met te stellen dat meer onderzoek naar de gedragingen van deze krachten nodig is, met name om hun invloed op de internationale harmonisatie van accounting standards te kunnen vaststellen.

\section{Ter afsluiting}

Zoals zo vaak van congressen wordt geconcludeerd, was ook dit een nuttig congres. Niet alleen vanwege de gepresenteerde papers doch ook vanwege de mogelijkheden om met anderen van gedachten te wisselen over de vele problemen die op het vakgebied leven.

Met betrekking tot de sociale kant van het congres is vermeldenswaard de overweldigende ontvangst door de heer Ramon Trias I Vargas, conseller d'economia i finances of the Generalitat of Catalonia. Tijdens de jaarvergadering van de EAA droeg Prof. Bouma het voorzitterschap over aan Prof. F. Pereira (IESI). Voorts werd besloten dat in 1982 het jaarlijks congres zal worden gehouden te Aarhus (Denemarken). Tevens werden de plaatsen voor het congres in 1983 en dat in 1984 aangewezen, resp. Glasgow en Sankt Gallen. Als meest geschikte datum voor het houden van de jaarcongressen kwam de week vóór Pasen ('Goede Week') naar voren.

In 1979 schreef ik dat de EAA in haar driejarig bestaan reeds heeft bewezen in een behoefte te voorzien. $\mathrm{Nu}$, twee jaar later, geldt dat des te meer, hetgeen ook tijdens het congres bleek.

Het aantal leden bedroeg ultimo juni 1981 406, waarvan 360 leden uit Europa (inclusief 4 leden uit 3 Oost-Europese landen). In totaal zijn de leden afkomstig uit 32 landen waarvan 12 niet-Europese landen. Ook in 1981 is GrootBrittannië qua aantal leden het sterkst vertegenwoordigd (124), nu gevolgd door Zweden (50), West-Duitsland (37). Nederland (32) hoeft de 4e plaats niet langer te delen met Frankrijk dat naar een gedeelde $5 \mathrm{e}$ en $6 \mathrm{e}$ plaats met Finland is afgezakt: ieder 24 leden.

Noten

1 Voor een wat uitvoeriger weergave verwijs ik naar 'Spanish Accounting in the Past \& Present'. Issues in Accountability no. 7 April 1981. Strathclyde Convergencies (ed. David Forrester.

University of Strathclyde, Glasgow).

2 Dit zijn: C. van Halem, Cost Accounting Information and Planning; J. Dijksma, Funds concepts in funds statements. 